\title{
DNA-based Identification and Descriptions of Immatures of Kempnyia Klapálek (Insecta:Plecoptera) from Macaé River Basin, Rio de Janeiro State, Brazil
}

ARTICLE in FRESHWATER SCIENCE · JANUARY 2014

Impact Factor: 1.94 · DOI: 10.1086/675226

CITATIONS

3

4 AUTHORS, INCLUDING:

Fernanda Avelino-Capistrano

Federal University of Rio de Janeiro

17 PUBLICATIONS 12 CITATIONS

SEE PROFILE
Daniela Maeda Takiya

Federal University of Rio de Janeiro

45 PUBLICATIONS 183 CITATIONS

SEE PROFILE 


\title{
DNA-based identification and descriptions of immatures of Kempnyia Klapálek (Insecta:Plecoptera) from Macaé River Basin, Rio de Janeiro State, Brazil
}

\author{
Fernanda Avelino-Capistrano ${ }^{1,2,3,4}$, Jorge Luiz Nessimian ${ }^{1,5}$, Jacenir Reis Santos-Mallet ${ }^{2,3,6}$, \\ and Daniela Maeda Takiya ${ }^{1,7}$ \\ ${ }^{1}$ Laboratório de Entomologia, Departamento de Zoologia, Instituto de Biologia, Universidade Federal do Rio de Janeiro, Caixa Postal \\ 68044, 21941-971, Rio de Janeiro, RJ, Brazil \\ ${ }^{2}$ Programa de Pós-Graduação em Biologia Animal, Universidade Federal do Rio de Janeiro, Caixa Postal 68044, 21941-971, Rio de \\ Janeiro, RJ, Brazil \\ ${ }^{3}$ Laboratório de Transmissores de Leishmanioses, Fundação Oswaldo Cruz, Rio de Janeiro, RJ, Brazil
}

\begin{abstract}
Deoxyribonucleic acid (DNA) barcode (cytochrome $c$ oxidase subunit I [COI]) sequences have been used to associate adult and immature stages of stoneflies as a rapid and effective alternative to rearing immatures. However, no molecular associations have been made for Neotropical species, which have very few described immature stages. Kempnyia Klapálek (Perlidae) is an endemic South American genus. Currently, 20 females have been associated with males of the 40 valid species, but only 5 nymphs have been described. We collected stonefly nymphs at Macaé River Basin, Rio de Janeiro State, Brazil, and Kempnyia nymphs were separated those in 6 morphotypes. These morphotypes were associated to nominal Kempnyia species using $38 \mathrm{COI}$ sequences (471 base pairs [bp]) of immatures and identified adults of 10 species occurring in southern and southeastern Brazil. Based on a neighbor-joining analysis of Kimura-2-parameter (K2P) pairwise divergences, we found 6 genetic Kempnyia lineages at Macaé River Basin represented by all morphotypes of nymphs included in our study. These nymphs were associated with males of Kempnyia alterosarum, K. colossica, K. gracilenta, $K$. petersorum, $K$. obtusa, and $K$. varipes. Intraspecific divergences in Kempnyia varied from 0 to $15 \%$, but $\sim 1 / 2$ of comparisons had values $>3 \%$. These data are in agreement with previous studies with stonefly populations, which tend to show high COI divergences. Based on our results, we described previously unknown immatures of $K$. alterosarum, $K$. petersorum, and $K$. obtusa, and the male genitalia of $K$. varipes for the first time. We also described a new adult color morph of $K$. petersorum. Our study increased the number of Kempnyia species recorded at Macaé River Basin from 5 to 11 . We recorded for the first time K. alterosarum and K. reticulata from Rio de Janeiro State and K. jatim from Espírito Santo State.
\end{abstract}

Key words: stoneflies, taxonomy, COI, Atlantic Forest

Benthic macroinvertebrates are the most commonly used freshwater organisms for assessing water quality because: 1) they are ubiquitous and can be used to detect environmental disturbances in many types of aquatic systems and 2) their large number of species offers a spectrum of responses to environmental stressors (Rosenberg and Resh 1993, Bae et al. 2005). Macroinvertebrates have been used in freshwater monitoring programs in the Neotropics (Galdean et al. 2000, Callisto et al. 2001, Buss et al. 2002) and indicate that stonefly nymphs are very sensitive to environmental change (Junqueira and Campos 1998, Miserendino and Pizzolón 1999). Most such studies in the Neotropics are based on identifications at the family level (e.g., Junqueira and Campos 1998, Miserendino and Pizzolón 1999) because of high diversity and the lack of appropriate taxonomic tools for identification at a lower level, even though some authors recommend identification at species level for greater sensitivity (Jones 2008, Sweeney et al. 2011).

Taxonomic descriptions of most Neotropical stoneflies are based only on adult males, and species identification of stonefly nymphs is almost impossible based on the published literature. Nymphal stages of few Neotropical spe-

E-mail addresses: ${ }^{4}$ fernandaacsilva@yahoo.com.br; ${ }^{5}$ nessimia@acd.ufrj.br; ${ }^{6}$ jacenir@ioc.fiocruz.br; ${ }^{7}$ takiya@ufrj.br 
cies have been described because of the difficulty of associating Plecoptera nymphs with adults. For example, adults often are not found with nymphs because females tend to fly upriver to oviposit (Müller 1954). Rearing nymphs to adults can be difficult because nymphs often die before reaching the laboratory (Novaes et al. 2012). Some authors have reared last-instar nymphs to the adult stage in the field to avoid transporting live specimens to the laboratory (Bispo et al. 2013). Avelino-Capistrano (2010) had some success rearing Kempnyia gracilenta (Enderlein) and K. reticulata (Klapálek) in the laboratory because they are more resistant to transportation death than other species (e.g., Anacroneuria debilis (Pictet)), and Novaes et al. (2012) reared nymphs of Anacroneuria ofaye Froehlich in an apparatus that simulates river currents. Nevertheless, most nymphal species remain unassociated.

Molecular tools have been used to associate immature and adult stages of insects (Mynott et al. 2011), address phylogenetic questions (Fochetti et al. 2009, 2011, Boumans and Baumann 2012) and cryptic species problems (Tiernode-Figueroa et al. 2011), and identify species based on the GenBank database (Hajibabaei et al. 2011, Sweeney et al. 2011). Use of molecular tools to associate life stages is rapid and effective (Miller et al. 2005, Caterino and Tishechkin 2006, Zhou et al. 2007, Hayashi and Sota 2010, TrivinhoStrixino et al. 2012) because genetic regions are identical in all life stages. Deoxyribonucleic acid (DNA) barcode sequences based on cytochrome $c$ oxidase subunit I (COI) have been used to associate adult and nymphal stoneflies in Australia (Gray 2009, Mynott et al. 2011) to provide diagnostic characteristics and tools for identification of nymphs. To date, no similar study has been done in the Neotropics.

Currently, 168 species of Plecoptera are recorded from Brazil. Of those, 40 occur in Rio de Janeiro State (Nessimian et al. 2009, Froehlich 2010, 2011a, b, Avelino-Capistrano et al. 2013). Only 8 species are recorded for Macaé River Basin in Rio de Janeiro State: Anacroneuria subcostalis Klapálek, A. petersi Froehlich, A. simulans Froehlich, Gripopteryx garbei Navás, Kempnyia obtusa Klapálek, K. puri Avelino-Capistrano, Souza \& Nessimian, K. serrana (Navás), and K. taunayi (Navás) (Nessimian et al. 2009, AvelinoCapistrano et al. 2013, Baldin et al. 2013). However, Baptista et al. (1998) found 13 morphotypes of stonefly nymphs in the Macaé River Basin while conducting an ecological study, a result highlighting the lack of taxonomic information for this region.

\section{MATERIALS AND METHODS}

\section{Background on Kempnyia (Perlidae) stoneflies}

Kempnyia is an endemic genus of Perlidae from South America and currently includes 40 species (Froehlich 2011a, b). The genus is distributed from central to southern Brazil, but may also occur in neighboring areas of Argentina, Paraguay, and Uruguay. Recently, nymphs were found in Venezuela (Derka et al. 2009). The genus was erected by Klapálek based on $K$. tenebrosa Klapálek from Teresópolis, Rio de Janeiro State (Stark et al. 2009). According to Stark et al. (2009), these insects can be characterized by: 1) presence of 2 or 3 ocelli, 2) head with short ridge extending from posterior margin to junction of epicranial suture, which bends forward between the ocelli, and 3) male sternum IX with hammer greatly variable. Nymphs of Kempnyia live in headwater areas of preserved rivers where they are found among the litter. Adults can be found flying or resting on vegetation near the stream (Dorvillé and Froehlich 2001, Henriques-Oliveira and Nessimian 2010). Kempnyia nymphs are used in freshwater biomonitoring in Brazil because they and other stoneflies are considered sensitive to chemical and physical changes (Mugnai et al. 2008). However, only 5 nymphs of Kempnyia are described and associated to nominal species: Kempnyia colossica (Navás), K. gracilenta (Enderlein), K. neotropica (Jacobson \& Bianchi), K. reticulata, and K. tijucana Dorvillé \& Froehlich (Dorvillé and Froehlich 2001, Bispo and Froehlich 2008, Avelino-Capistrano et al. 2011, Bispo et al. 2013). We collected Kempnyia Klapálek nymphs in the Macaé River Basin and used DNA barcodes to associate them with identified males occurring in southeastern Brazil.

\section{Study area}

Macaé River is the largest river entirely within the State of Rio de Janeiro, Brazil. Its basin covers $\sim 1765 \mathrm{~km}^{2}$ and includes part of the cities of Nova Friburgo, Casimiro de Abreu, Rio das Ostras, Conceição de Macabu, Carapebus, and Macaé, where $82 \%$ of the basin occurs. Macaé River begins at Pico do Tinguá (Nova Friburgo) at $1560 \mathrm{~m}$ asl at Serra de Macaé in the Atlantic Rain Forest and empties into the Atlantic Ocean at Macaé $(136 \mathrm{~km})$. The river receives rural and urban domestic sewage, and only the headwaters are well preserved (SEMADS 2001). We sampled at 105 collecting stations throughout the basin (altitudes were 7-1103 $\mathrm{m}$ asl) along a gradient from well preserved to impacted (Nova Friburgo, Casimiro de Abreu, and Macaé municipalities).

\section{Specimen sampling}

We collected most of our study material between November 2008 and September 2010. We collected nymphs manually and adults with light traps, and fixed and preserved all specimens in $93 \%$ ethanol to maximize DNA preservation. We also included specimens from the Macaé River Basin previously deposited at Coleção Entomológica by José Alfredo Pinheiro Dutra (DZRJ; Universidade Federal do Rio de Janeiro). We included identified Kempnyia males collected at other localities in southern or southeastern Brazil in the DNA study (Appendix S1), when these species were not represented by males from Macaé River Basin. 


\section{Specimen imaging}

We took optical photographs of the material with the aid of a stereomicroscope (MZ16; Leica, Wetzlar, Germany) and a coupled camera (Leica DFC420). We stacked images with the softwares Auto-Montage ${ }^{\circledR}$ (Synoptics, Frederick, Maryland) and Leica IM50. We took scanning electron micrographs (SEMs) of 2 nymphs of each species. We rehydrated nymphs in a series of 70,50,30, and 15\% alcohol for 10 min each and washed them in $\mathrm{pH} 7.2$ sodium cacodylate buffer for $10 \mathrm{~min}$ before fixation in $2.5 \%$ glutaraldehyde and postfixation in $1 \%$ osmium tetroxide for $1 \mathrm{~h}$. After washing in the same buffer, we dehydrated nymphs in a series of increasing ethanol concentrations and submitted them to critical-point drying, using superdry $\mathrm{CO}_{2}$ in Balzer's apparatus. We set the dried material on metallic stubs, covered it with a thin layer of $\mathrm{Au}(20-30 \mathrm{~nm})$, and observed it via a JSM-6390LV scanning electron microscope (JEOL, Tokyo, Japan) at the Electron Microscopy Platform, Instituto Oswaldo Cruz, Fundação Oswaldo Cruz.

\section{DNA sequences}

We extracted DNA from all identified adults and included males and females that occurred at the same site. We also extracted DNA from nymphs collected at sites where identified adults were present to increase the likelihood of association. In addition, we extracted DNA from 5 nymphs of each morphotype, when available, even if no adults had been collected. We used the DNeasy ${ }^{\circledR}$ Blood and Tissue Kit (Qiagen, Hilden, Germany) to extract DNA following a modified protocol from the manufacturer's instructions and amplified partial COI by polymerase chain reaction (PCR) using the primers LCO-1490 or C1-J-1718 in combination with HCO-2198 (Folmer et al. 1994, Simon et al. 1994). We used a 2-part PCR program with 5 initial cycles with annealing temperature of $45^{\circ} \mathrm{C}$ followed by 35 cycles with annealing temperature of $51^{\circ} \mathrm{C}$. PCR amplifications were purified and sequenced by Macrogen (Seoul, Korea). Chromatograms were viewed and consensus sequences were adjusted manually with Sequencher 4.14 (Gene Codes, Ann Arbor, Michigan). Sequences were checked with Basic Local Alignment Search Tool (BLAST; Altschul et al. 1997) against the GenBank nucleotide database to check the amplified product. Alignment of sequences was done with ClustalW (Thompson et al. 1994) in MEGA (version 5.1; Tamura et al. 2011). For some species, bases obtained only at the start or end of the alignment were trimmed. The result was a 471-base pair (bp) alignment of 38 sequences for Kempnyia and 3 outgroup sequences (Anacroneuria debilis, A. itatiaiensis Baldin, Bispo et Novaes, and Paragripopteryx sp.).

\section{Phylogenetic analyses}

We calculated pairwise distances corrected using the Kimura-2-parameter (K2P) model of evolution in MEGA and clustered sequences via neighbor-joining (NJ) with 500 bootstrap replicates. We conducted a Bayesian analysis (2 independent runs of 4 Monte Carlo-Markov Chains for 1 million generations, 25\% generation burn-in) in MrBayes (version 3.2.2; Ronquist et al. 2013) to assess support and monophyly of the clades recovered. We used jModelTest (Posada 2008) to choose the evolutionary model HasegawaKishino-Yano + invariant + gamma $(\mathrm{HKY}+\mathrm{I}+\mathrm{G})$ on the basis of Akaike's Information Criterion as the best model for the COI sequences.

\section{RESULTS}

\section{Nymphal and female associations}

We identified 10 distinct lineages or well supported clusters of Kempnyia (bootstrap and Bayesian posterior probabilities) in the NJ analysis (Fig. 1; color version available online). Three of these clades included conspecific males identified through male genital characters. Distances between males were $4.6 \%$ for $K$. petersorum (Froehlich), $9.6 \%$ for $K$. obtusa, and up to $15.1 \%$ for $K$. colossica. We assumed the highest value as the cutoff for maximum intraspecific divergences and used these values to delimit specific lineages that included $\geq 1$ specimen. We separated unidentified nymphs into 6 morphotypes and associated representatives of morphotypes to male adults of $K$. alterosarum Froehlich, $K$. colossica, $K$. gracilenta Enderlein, $K$. obtusa, K. petersorum Froehlich, and K. varipes Klapálek. We separated adult female specimens into 3 morphotypes and associated representative specimens of each morphotype to identified males of $K$. gracilenta, $K$. jatim Froehlich, and $K$. petersorum.

\section{COI intra- and interspecific divergences}

Pairwise K2P corrected $p$-distances between all sequences are given in Table S1. Within the 29 Kempnyia specimens studied, minimum intraspecific divergences were 0.0 to $10.7 \%$, and maximum intraspecific divergences were 4.6 to $15.1 \%$ ( $K$. alterosarum: $6.4 \%$; K. colossica: 10.7 to $15.1 \%$, mean $=13.0 ; K$ gracilenta: 0.0 to $11.2 \%$, mean $=$ 3.1; K. jatim: 0.2 to $7.7 \%$, mean $=5.1 ; K$. obtusa: 0.4 to $9.6 \%$, mean $=6.4 ; K$. petersorum: 0.0 to $4.6 \%$, mean $=1.7$; and $K$. varipes: 5.5 to $9.6 \%$, mean $=8.0)$. Interspecific intrageneric divergences ranged from 7.5 to $25.0 \%$ (mean $=19.1$ ). Thus, Kempnyia specimens showed an overlapping barcode gap (Fig. 2).

\section{Kempnyia occurring in Macaé River Basin}

We found 11 Kempnyia species in the Macaé River Basin. Four of these species were previously recorded from this basin ( $K$. obtusa, $K$. serrana, $K$. taunayi, and K. puri), but we did not collect the latter 3 species during our study. Thus, we recorded 7 new Kempnyia species from this basin based on our study of 240 specimens 


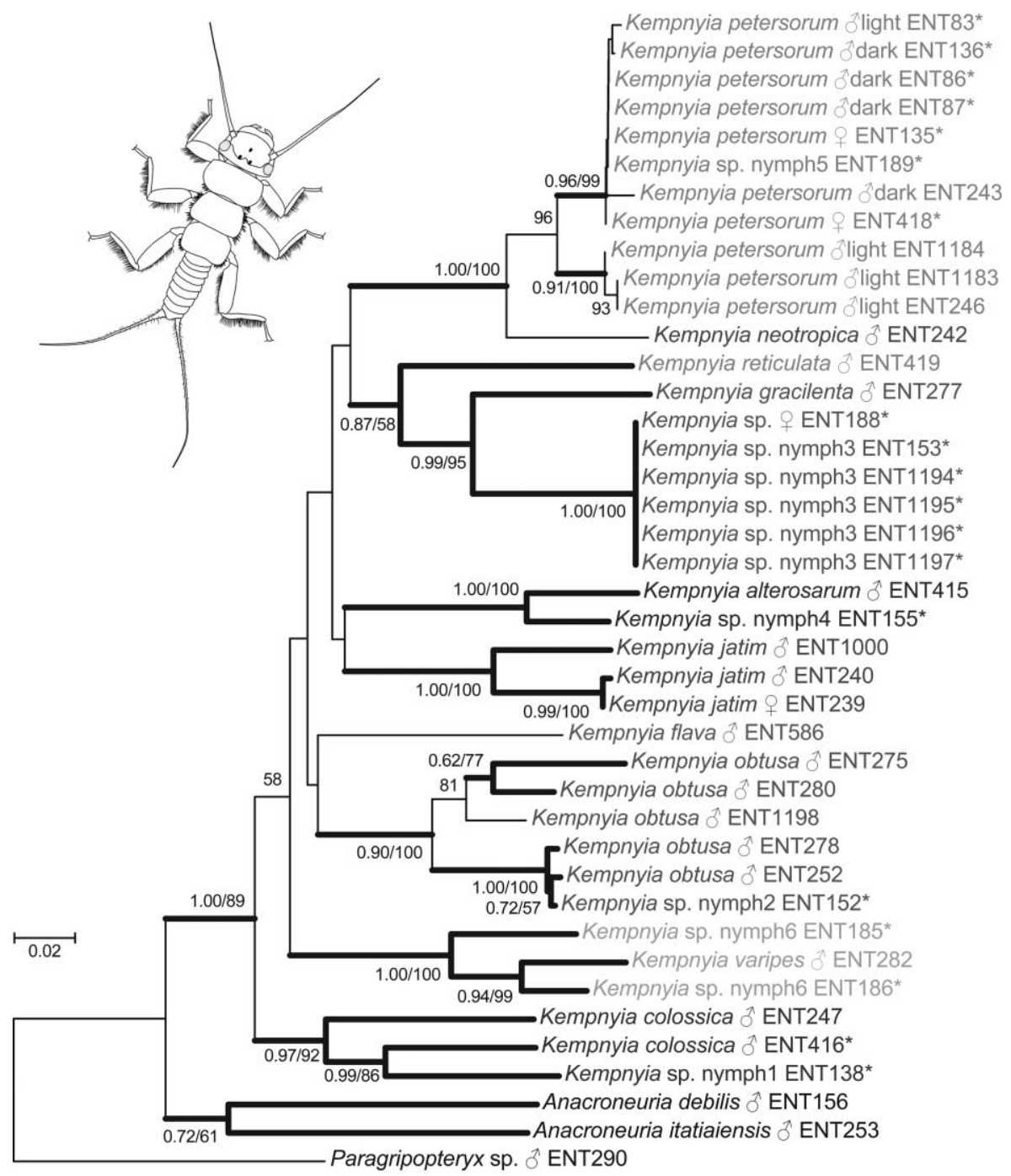

Figure 1. Neighbor-joining tree for cytochrome $c$ oxidase subunit I (COI) sequences (471 base pairs) from Kempnyia and related stoneflies from southeastern and southern Brazil modeled by Kimura-2-parameter (K2P). The tree is rooted with a representative of Gripopterygidae. Clades shown with thick lines were recovered in the Bayesian analysis. Numbers are Bayesian posterior probabilities (when existing)/bootstrap percentages $>50 \%$. Colors correspond to Kempnyia species clades. * indicates specimens collected in Macaé River Basin.

(169 nymphs, 67 adults) collected at 23 of the 105 stations. Among the adults, 39 males represented 5 Kempnyia species: K. colossica, K. gracilenta, K. jatim, K. petersorum, and $K$. obtusa. We separated nymphs into 6 morphotypes and identified 1 morphotype as $K$. reticulata based on the nymphal morphological description given by AvelinoCapistrano et al. (2011). This record is the $1^{\text {st }}$ for this species in Rio de Janeiro State. We used COI to associate 2 of these unidentified nymphal morphotypes with adult male $K$. alterosarum and $K$. varipes from other localities.

Morphological descriptions of previously unknown immatures, $K$. alterosarum, $K$. obtusa, and $K$. petersorum and a new color morph of the male adult of $K$. petersorum are given below. The species $K$. varipes was originally described based only on external morphology. Therefore, we have in- cluded the adult male and associated nymphs. Short descriptions and notes on other studied species are given below. Head measurements are the maximum width of the head capsule. Forewing measurements are the distance from the base of the anal lobe to the wing apex. For nymphs, wing pad measurements refer to the distance from the anterior margin of the mesonotum to the tips of wing pads. Morphological terminology follows Stark et al. (2009).

\section{DESCRIPTION OF SPECIES AND REMARKS} Kempnyia alterosarum Froehlich, 1988 (Fig. 3A-G; color version available online)

Description. Distribution Brazil. Minas Gerais and Rio de Janeiro (new record) states. 


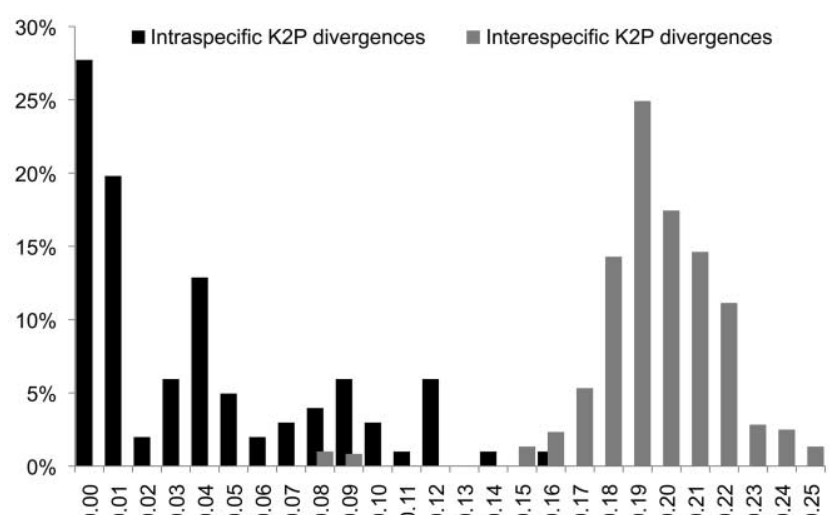

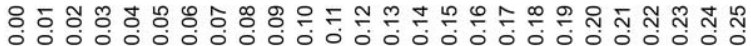

Figure 2. Percentages of pairwise intra- and interspecific comparisons by Kimura-2-parameter (K2P) divergences showing an overlapping barcode gap of Kempnyia specimens.

Material examined Brazil. MG: Itabirito, 20' [ENT415]; Itamonte, 10'. RJ: Nova Friburgo, 1n [ENT155].

Measurements Nymph $(n=1)$. head: $3.36 \mathrm{~mm}$; wing pads: $3.37 \mathrm{~mm}$. Adult male $(n=3)$. head: $2.03-2.62 \mathrm{~mm}$; forewing: $12.13-15.26 \mathrm{~mm}$.

Nymph General color stramineous. Head with labrum and anterior frons with reddish brown band; posterior area of frons, clypeus, and parietalia, light brown (Fig. 3A). M-line light brown, but poorly delimited. Epicranial suture not exceeding the paired ocelli. Three ocelli partially black. Eyes black. Spines covering $1 / 3$ of ocular sclerite. Antennae light brown (Fig. 3A, B). Pronotum rectangular, brown with a yellow area forming a characteristic pattern, covered by dark brown bristles (Fig. 3A); flange light brown, with margin brown; posterior flange area thicker than lateral. Meso- and metanotum stramineous with lighter spots (Fig. 3C), and with many spines laterally arranged. Pro-, meso-, and metanotum covered with many setae. Thoracic gills present: ASC [1,2,3], PSC [1,2,3], PT [3], and AT[1,2]. Legs stramineous, with longitudinal row of plumose setae on femur, tibia, and reduced on tarsi (Fig. 3D, E); numerous reddish-brown spines covering the femur in dorsal view; in ventral view, these spines are sparse and fewer in number; longitudinal row of reddishbrown spines along tibia (Fig. 3D, E). Abdomen, in dorsal view brown, becoming darker to the apex; in the each segment, posterior margin is darker; a row of spines is disposed on the base of each tergum (Fig. 3F); tergum X dark brown (Fig. 3G); general color yellow in ventral view, except by the last 5 segments of abdomen, which become brown to dark brown. Anal gills present (Fig. 3G). Cerci brown, bearing long bristles; brown spines are present in each article of the cerci. Moderate number of long fine bristles covering the base of cerci (Fig. 3G); each cercus article with a ring of 10 spines.

Remarks Froehlich (1988) described this species from Serra do Cipó (Minas Gerais State) based on many male
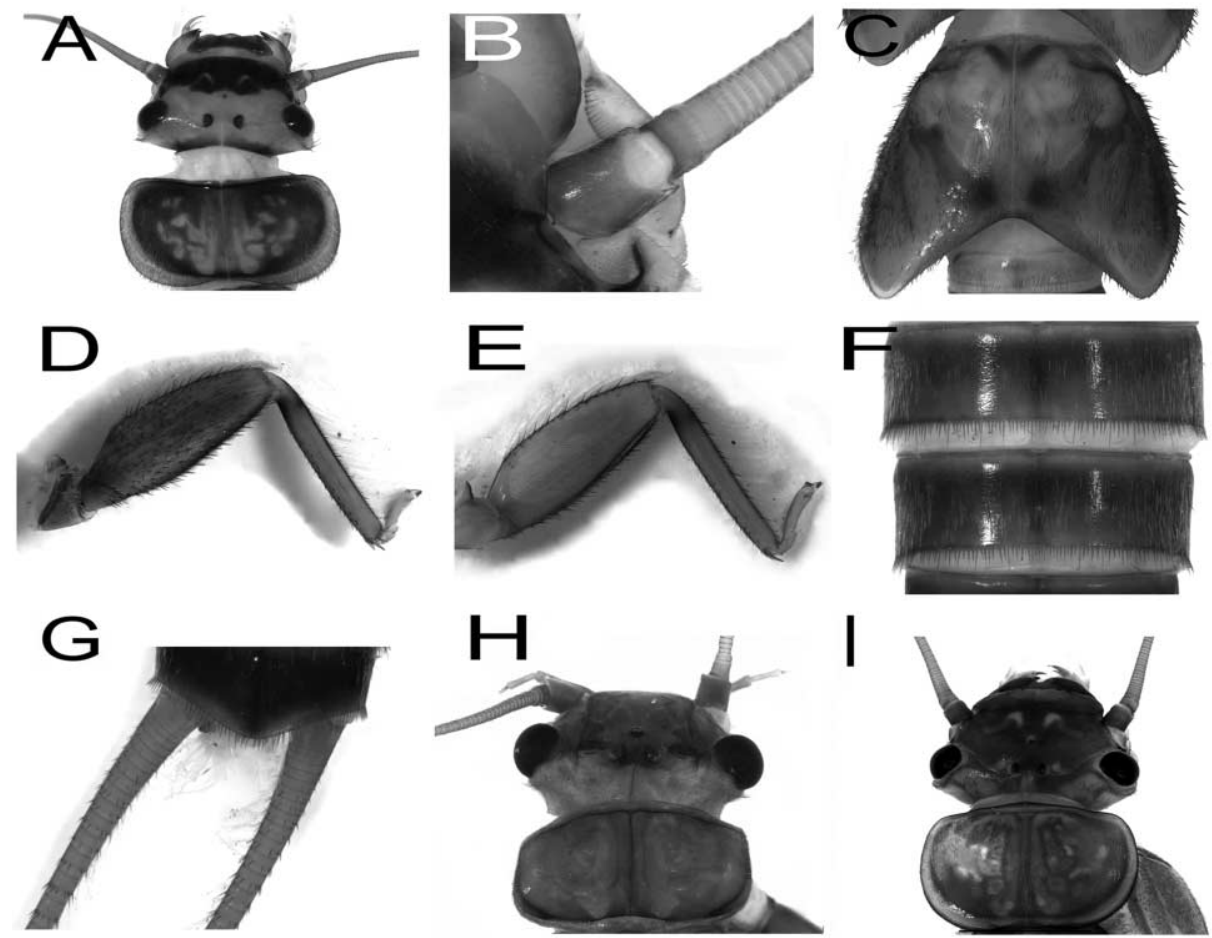

Figure 3. Kempnyia alterosarum Froehlich. Nymph: A.-Head and pronotum; B.-Flagellum of antennae, dorsal view; C.-Metanotum; D.-Foreleg, anterior view; E.-Foreleg, posterior view; F.-Tergum VI-VIII; G.-Tergum X and cerci. Kempnyia colossica (Navás). Adult male: H.-Head and pronotum. Nymph: I.-Head and pronotum. 
and female specimens. No nymphs have been previously described. No additional records are available for this species from southeastern Brazil, and ours is the $1^{\text {st }}$ record for Rio de Janeiro State. No adults were collected, and only 1 nymph from Nova Friburgo was associated with specimens from Itabirito and Itamonte. Males from Itabirito were smaller than the male from Itamonte, but both males were in the range of measurements given by Froehlich (1988). The nymph is larger than the adult males from Minas Gerais State and differs from other Kempnyia nymphs by the color pattern, a brown ring on anterior tibia, and few long bristles on cerci base (see Fig. 3A-G).

\section{Kempnyia colossica (Navás, 1934) (Fig. 3H, I; color version available online)}

Description. Distribution Brazil. Minas Gerais, Paraná, Rio de Janeiro, Santa Catarina, and São Paulo states.

Material examined Brazil. MG: Itamonte, 6n. RJ: Nova Friburgo, 30' [ENT416], 1n [ENT138]; SP: São José do Barreiro, 30' [ENT247].

Measurements Nymph $(n=7)$. head: $3.57-6.50 \mathrm{~mm}$; wing pads: $2.82-8.00 \mathrm{~mm}$. Adult male $(n=6)$. head: 3.33-4.41 mm; forewing: 24.76-29.60 mm.

Nymph (additional characters) General color reddishyellow dorsally and whitish yellow ventrally. Eyes black with white contour; 3 black ocelli, light comma-like paired spots beside ocelli (Fig. 3I). Pronotum oval, with many bristles; surface rugose forming a pattern of ornamentation; flange thin, with parts sometimes darker. Meso- and metanotum darker on anterior margin than posterior margin. Legs with femora and tibiae with a fringe of brown bristles. Abdomen reddish-brown with longitudinal line light brown.

Remarks Navás (1934) described this species as Laeissa colossica based on an exemplar from Nova Bremen (now Presidente Getúlio, Santa Catarina State). Froehlich (1988) transferred this species to Kempnyia based on characteristics shared with Kempnyia brasiliensis (Pictet) (large size and type of penial armature). He pointed out differences between males from Santa Catarina and Campos do Jordão, especially in the size and shape of penial armature. Specimens from Rio de Janeiro State (Fig. 3H, I) are similar to the specimen from Santa Catarina State with penial armature similar to that illustrated by Froehlich (1988; Fig. 3G-I). The nymph of this species was recently described by Bispo et al. (2013) based on material from Paranapiacaba Mountains (São Paulo State) and is similar to those analyzed from Nova Friburgo. Characters given in the nymphal description above were not cited in this description or are slightly different.

\footnotetext{
Kempnyia gracilenta (Enderlein, 1909) (Figs S1A-H, $4 \mathrm{~A}-\mathrm{C}$; color version available online)

Description. Distribution Brazil. Espírito Santo, Minas Gerais, Rio de Janeiro, and São Paulo states.
}

Material examined Brazil. ES: Castelo, 30' [ENT277]. Santa Teresa, 10' 1오 RJ: Nova Friburgo, 1 우 [ENT188], 38n [ENT153, 1194, 1195, 1196, 1197].

Measurements Nymph $(n=38)$. head: $1.73-4.12 \mathrm{~mm}$; wing pads: $1.11-4.01 \mathrm{~mm}$. Adult female $(n=2)$. head: 3.25-3.27 mm; forewing: $19.6-21.50 \mathrm{~mm}$. Adult male ( $n$ = 4). head: 2.32-2.46 mm; forewing: 14.17-15.68 mm; penial armature: $1.80 \mathrm{~mm}$.

Nymph (additional characters) Spines covering $1 / 2$ of ocular sclerite (Fig. S1A). Antennae bearing light brown bristles; each flagellomere bearing tufts of short digitiform setae (Fig. S1B). Pronotum rectangular (Fig. S1C). Femora covered by numerous spines and bristles (Fig. S1D, E). Thoracic gills present: ASC [1,2,3], PSC [1,2,3], PT[3], and $\mathrm{AT}[1,2]$. Abdomen light brown; a row of spines on posterior margin of each tergum (Fig. S1F); numerous long fine bristles covering the base of cerci (Fig. S1G, H); long brown spines on basal articles of cerci (Fig. S1G, H). Anal gills present (Fig. S1G).

Remarks Enderlein (1909) described K. gracilenta from adult males and females from Espírito Santo State. The species is recorded from Rio de Janeiro (Petrópolis, Teresópolis; Jewett 1960), Minas Gerais (Serra do Caraça; Froehlich 1984), and São Paulo (Campos do Jordão; Froehlich 1984). The female subgenital plate of $K$. gracilenta was drawn by Froehlich (1984), but later this author attributed these figures (1-3) as belonging to K. tamoya (Froehlich 2011a). We did not examine the material studied by Froehlich, but specimens of $K$. gracilenta reared by Avelino-Capistrano et al. (2011) (Fig. 4A) and the female associated to this species from Macaé River Basin [ENT188] (Fig. 4B, C) agree with the original figures by Froehlich (1984).

\section{Kempnyia obtusa Klapálek, 1916 (Figs 4D, S2A-H; color version available online)}

Description. Distribution Brazil. Minas Gerais, Rio de Janeiro, and São Paulo states.

Material examined Brazil. ES: Alto Caparaó, $10^{7}$ [ENT275]. MG: Itabirito, 10' [ENT280]. RJ: Nova Friburgo, 30', 31n [ENT152]; Petrópolis, 40' [ENT252, 1198]. SP: São José do Barreiro, 40', 2 우 [ENT278].

Measurements Nymph $(n=31)$. head: $1.25-5.14 \mathrm{~mm}$; wing pads: $0.73-5.23 \mathrm{~mm}$. Adult male $(n=13)$. head: 2.40-3.24 mm; forewing: $15.49-20.60 \mathrm{~mm}$. Adult female $(n=2)$. head: $2.19-2.81 \mathrm{~mm}$; forewing: $18.84-19.42 \mathrm{~mm}$.

Nymph General color stramineous, with dark bristles (Fig. 4D). Head with dark brown area, with arched stains, ranging from lateral margin of clypeus to area between the ocelli (Fig. 4D). Labrum brown. Clypeus with anterior margin brown. M-line barely evident, with glabrous surface. Epicranial suture does not exceed paired ocelli. Three ocelli completely black. Eyes black. Spines covering basal $1 / 3$ of ocular sclerite (Fig. S2A). Antennae stramineous, with brown setae on scape base of pedicel (Fig. S2B) and in each 

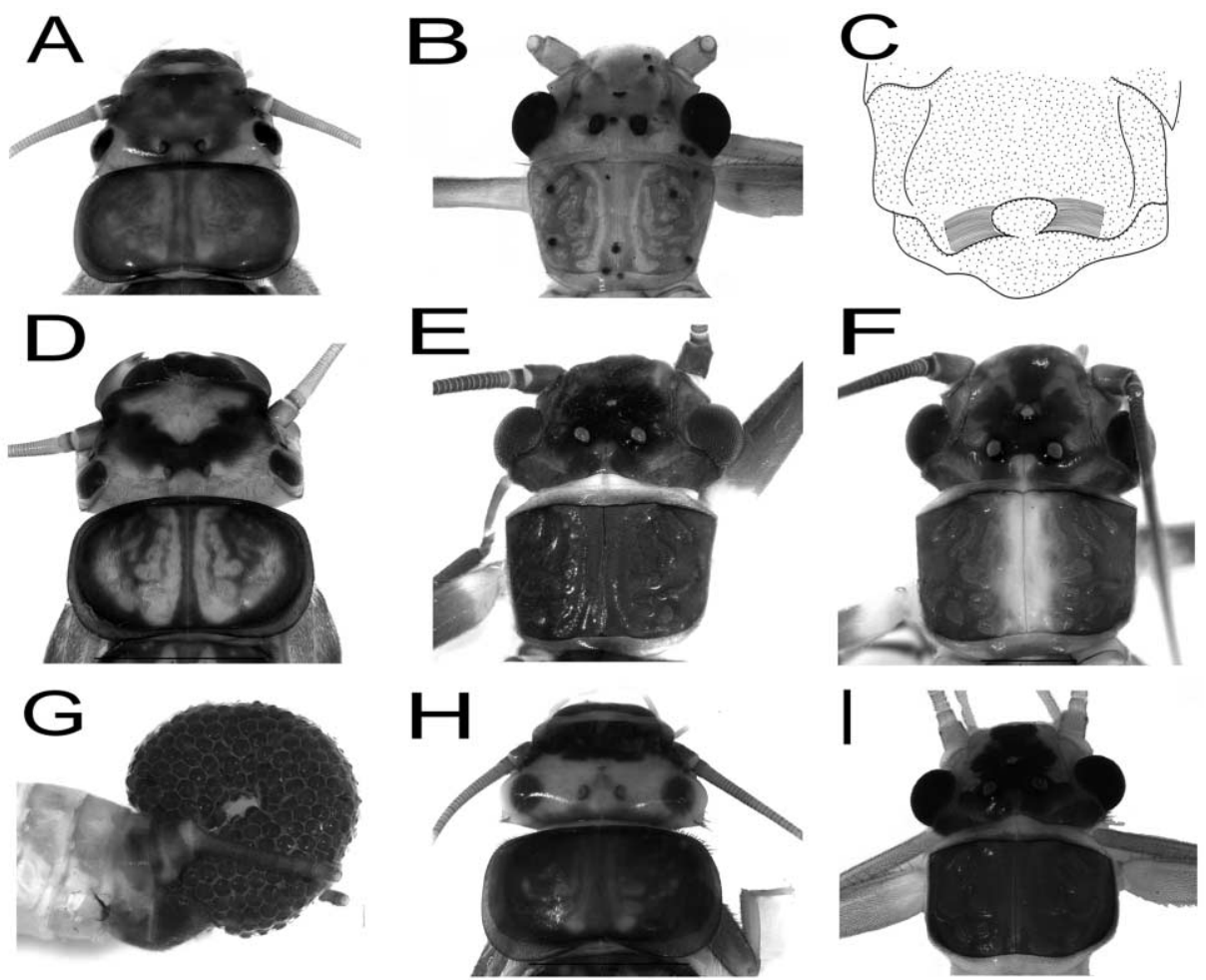

Figure 4. Kempnyia gracilenta (Enderlein). Nymph: A.-Head and pronotum. Adult female: B.-Head and pronotum; C.-Female subgenital plate. Kempnyia obtusa Klapálek. Nymph: D.-Head and pronotum. Kempnyia petersorum Froehlich. Adult male: E.-Dark brown morph, head and pronotum. Adult female: F.-Dark brown morph, head and pronotum; G.-Subgenital plate and egg mass. Nymph: H.-Head and pronotum. Adult male: I.-Light brown morph, head and pronotum.

flagellomere. Pronotum oval shape (Fig. S2C); anterior margin brown; lateral and posterior margins light brown; marginal groove of pronotal disc brown; 2 longitudinal pale lines parallel to median line suture, forming a characteristic pattern. Meso- and metanotum covered by numerous bristles (Fig. S2D); general color light brown with pale areas forming a characteristic pattern. Thoracic gills present: ASC [1,2,3], PSC [1,2,3], PT[3], and AT[1,2]. Legs yellow with brown stripe; a row of silver plumose setae on femur and tibia (Fig. S2E, F); numerous bristles covering the femur; spines present near on anterior and posterior margins of dorsal surface of femur. Abdomen light brown; posterior margin of each segment brown; a row of spines on posterior margin of each tergum (Fig. S2G); tergum X brown; in ventral side, all segments are pale brown, except segment $\mathrm{X}$. Anal gills absent (Fig. S2H). Cerci with few long bristles on the base (Fig. S2H), reducing in number and in size to apex; brown spines are present on each article.

Remarks Klapálek described Kempnyia obtusa based on male specimens from Teresópolis (Rio de Janeiro State). Specimens from Rio de Janeiro, Minas Gerais, and São Paulo states agree with the original description, except the material from Serra do Caparaó, where specimens were smaller. Froehlich (1988) later recorded females from Serra de Macaé and Parque Nacional do Itatiaia, but immatures of this species were previously unknown. Nymphs are char- acterized by the characteristic pattern of the pale area on the head (Fig. 4D), by dark brown stripes on the femur, absence of anal gills (Fig. S2H), and many long bristles at cerci base.

Kempnyia petersorum Froehlich, 1996 (Figs 4E-I, S3A-H; color version available online)

Description. Distribution Brazil. Minas Gerais, Rio de Janeiro, Paraná, and São Paulo states.

Material examined Brazil. RJ: Nova Friburgo, 207 [ENT83], 6Q, 2n [ENT189]; Macaé, 110 [ENT86, 87, 136], 5ㅇ [ENT135, 418], 4n; Petrópolis, 207 [ENT243], 2Q. PR: Morretes, 30' [ENT246, 1183, 1184]. SP: Iporanga, $30^{7}, 2$ ㅇ. MG: Itabirito, $10^{\prime}$.

Measurements Nymph $(n=6)$. head: $2.42-3.99 \mathrm{~mm}$; wing pads: $1.73-4.10 \mathrm{~mm}$. Adult male $(n=22)$. head: 1.49-2.48 mm; forewing: $8.20-14.61 \mathrm{~mm}$. Adult female $(n=15)$. head: $2.35-3.11 \mathrm{~mm}$; forewing: $13.25-19.39 \mathrm{~mm}$.

Adult male, dark brown morph General color brown (Fig. 4E). Eyes black. Three ocelli partially black. Central area of head dark brown; lateral side brown; yellow heartshaped spot inside loop of epicranial suture. Antennae light brown; scape of antennae brown. M-line present, lighter than the rest of head. Epicranial suture does not exceed the paired ocelli. Pronotum rectangular and brown; 
very rugose. Wings brown, with dark brown veins. Legs brown with fore coxae, fore trochanters, and base of fore tibiae yellow; other legs with same color, but brown area at tibiae starts at middle ( $2^{\text {nd }}$ legs $)$ and apical end ( $3^{\text {rd }}$ legs). Abdomen light brown in dorsal and ventral views. Cerci brown, with many spines in the base reducing in number apically; many bristles covering all cerci. Tergum $\mathrm{X}$ with peg-like area, with few and sparse spines; paraprocts digitiform. Subgenital plate round; hammer subtriangular (similar to fig. 10 in Froehlich 1996). Penial armature as illustrated by Froehlich (1996; figs 13-15).

Adult female, dark brown morph Color pattern similar to male (Fig. 4F), but with distinct yellow longitudinal median band on pronotum. Subgenital plate rounded and brown. Egg mass violet (Fig. 4G).

Nymph General color brown. Head with brown area anterior to anterior ocellus extending to frons; clypeus brown (Fig. 4H). M-line not evident. Epicranial suture does not exceed paired ocelli. Three ocelli partially black. Eyes black. Spines are present only at base of the compound eyes (Fig. S3A). Antennae yellow; scape brown with setae (Fig. S3B). Pronotum subtrapezoidal brown (Figs 4H, S3C), with a pale area forming characteristic pattern; flange thin laterally, and thicker posteriorly. Meso- and metanotum light brown with lighter spots; with many spines laterally arranged (Fig. S3D). Thoracic gills present: ASC [1,2,3],
PSC [1,2,3], PT[3], and AT[1,2]. Posterior margin of each segment of abdomen brown with a row of spines on posterior margin of each tergum (Fig. S3E). Legs yellow, with sparse row of setae on femora (Fig. S3F) and tibiae, sparser on tarsi. Abdomen brown, darkening towards segment X; row of spines on posterior margin of each tergum (Fig. S3G); tergum X dark brown. Cerci with few bristles only at base (Fig. S3G, H); brown spines present in each article. Anal gills absent (Fig. S3G).

Remarks The nymph described herein differs from other Kempnyia nymphs by the dark brown color pattern of the head, similar to the nymph of $K$. neotropica described by Bispo and Froehlich (2008). However, these nymphs could be distinguished by the absence of anal gills in $K$. petersorum. Based on the molecular association, adult specimens described above as dark brown morphs are conspecific with individuals with the typical (originally described) light brown color pattern (Fig. 4I). Both color morphs occur at Macaé River Basin (see discussion).

\section{Kempnyia varipes Klapálek, 1916 (Figs 5A-H, S4A-H;} color version available online)

Description. Distribution Brazil. Rio de Janeiro State.

Material examined Brazil. RJ: Nova Friburgo, 6n [ENT186]; Macaé, 1n [ENT185]; Teresópolis, 40' [ENT282].

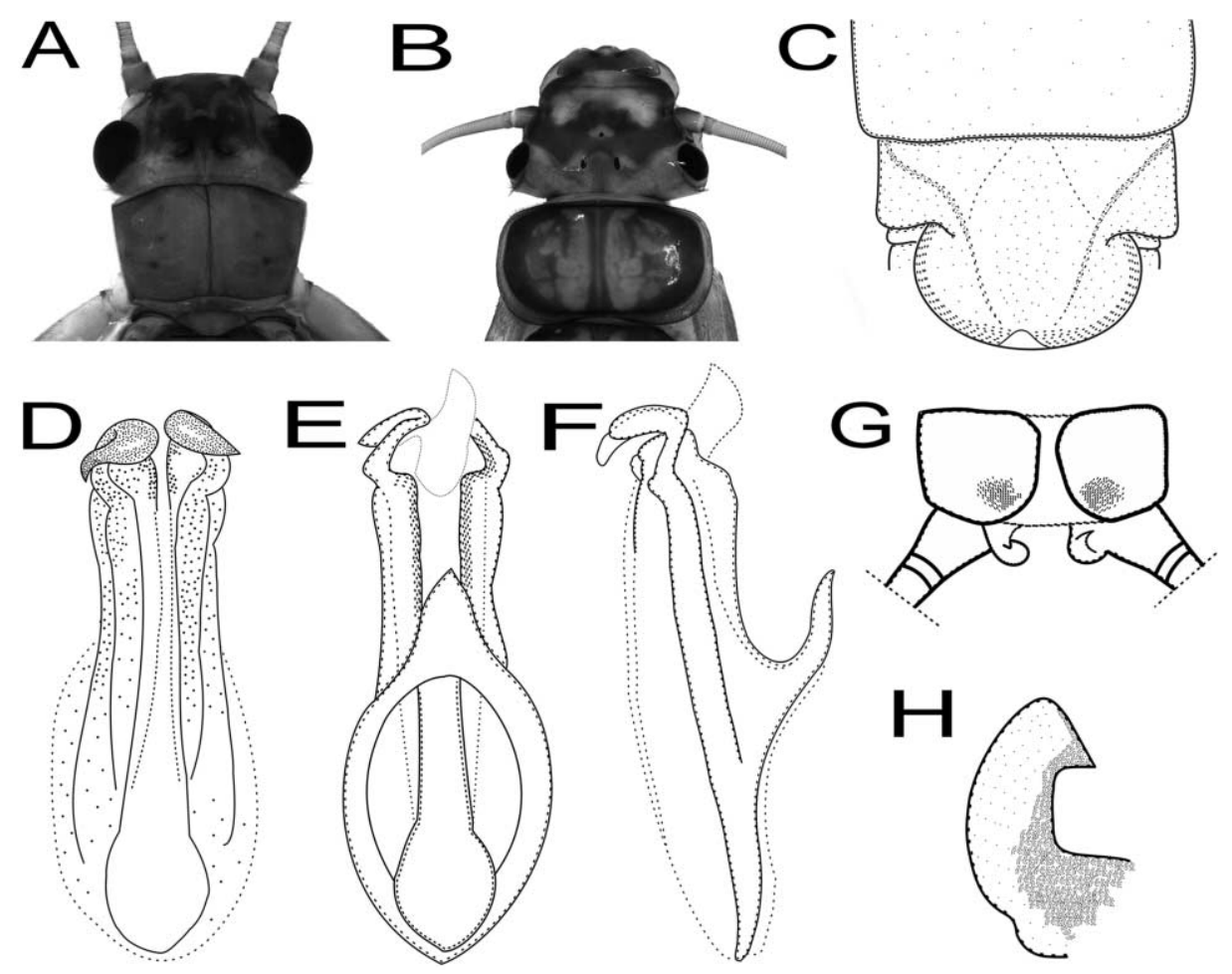

Figure 5. Kempnyia varipes Klapálek. Adult male: A.-Head and pronotum. Nymph: B.-Head and pronotum. Adult male: C.-Tergum X; D-F.-Penial armature, dorsal, ventral, and lateral views; G.-Subgenital plate and hammer; H.-Right paraproct, lateral view. 
Measurements Nymph $(n=7)$. head: $2.87-4.22 \mathrm{~mm}$; wing pads: $2.65-3.31 \mathrm{~mm}$. Adult male $(n=4)$. head: $2.49-$ $2.98 \mathrm{~mm}$; forewing: $15.44-17.53 \mathrm{~mm}$.

Male General color, in dorsal view brown, with light spots along the body (Fig. 5A). Ventral side pale. Head covered with many setae. M-line present. Three ocelli partially black. Eyes black. Antennae yellow and covered by many setae. Epicranial line does not exceed ocelli. Pronotum trapezoidal, brown laterally and lighter on disc. Wings light brown; veins of forewings light brown, excepting $R, r$, $\mathrm{Cu}$, and $\mathrm{A}$. Legs yellow, except by dark brown area at femoral base, and at base and apex of tarsus. Abdomen and cerci covered by numerous bristles. Cerci light brown. Subgenital plate rectangular and outlined by brown; hammer triangular (Fig. 5C). Penial armature dark brown. Hooks making a compact curve (comma-shaped) (Fig. 5D-F). Ring with median projection (Fig. 5E, F) with pointed apex. Tergum X with areas with peg-like bristles (Fig. 5G). Paraprocts directed dorsally with sharp point near apex (Fig. 5H).

Nymph General color stramineous (Fig. 5B). Head with labrum light brown; clypeus with lateral areas light brown; front with broad light-brown macula posteriorly, with small stramineous spot surrounding anterior ocellus. Mline not evident. Epicranial suture exceeding paired ocelli. Eyes black; with spines at base (Fig. S4A). Antennae yellow, with few setae on scape (Fig. S4B). Pronotum oval, borders of disc and median longitudinal band light brown; pronotal flange thicker posteriorly and wider laterally, with some spines at apex and base (Fig. S4C). Meso- (Fig. S4D) and metanotum light brown with lighter spots, with many spines laterally. Legs yellow; in dorsal view, femora covered by bristles and spines; longitudinal fringe of bristles on femora and tibiae (Fig. S4E). Abdomen light brown; a row of spines on posterior margin of each tergum (Fig. S4F). Anal gills present (Fig. S4G). Cerci moderately covered by long bristles at base, reducing in number and size towards the apex, but a tuft is present on final segments; each segment bearing brown spines (Fig. S4H).

Remarks This species has comma-shaped hooks similar to $K$. alterosarum, $K$. vanini Froehlich, and K. tupinamba Froehlich, but the median projection of the penial ring and the absence of spiny patches on the penial tube separate $K$. varipes from the others. This projection can be found in $K$. reticulata and $K$. tijucana, but these species have differently shaped hooks. The nymph is characterized by the epicranial suture that exceeds the paired ocelli, and the light-brown color delimited by pale areas, forming a characteristic pattern on the head and pronotum.

\section{DISCUSSION}

\section{COI intra- and interspecific divergences}

COI intraspecific and intraspecific divergences are commonly reported in DNA barcoding studies (Bergsten et al. 2012). Both are used to calculate the barcode gap, which affects the accuracy of species identifications. Early studies of intraspecific variation indicated barcode gaps $<3 \%$ divergence in insect species and $>8 \%$ divergence in most animals studied (Hebert et al. 2003a, b). However, substitution rates are heterogeneous in mitochondrial DNA, so universal thresholds for divergences should not be assumed in species delimitations (Galtier et al. 2009).

We regarded unidentified nymphs and females as conspecific with identified males when they formed a monophyletic group and their maximum divergence was less than the maximum intraspecific divergence found between 2 males identified on the basis of morphological characters. Intraspecific divergences varied from 0 to $15.1 \%$ (Table $\mathrm{S} 1$ ), but $\sim 1 / 2$ of comparisons had values $>3 \%$. The maximum divergence was found between 2 male specimens of $K$. colossica (ENT247 vs ENT416). These intraspecific divergence values seem high when compared to those for other insects (Zhou et al. 2009, Hayashi and Sota 2010, Park et al. 2011, Renaud et al. 2012), but the stoneflies studied so far tend to show high intraspecific divergences. For perlids, Fochetti et al. (2011) reported maximum intraspecific divergences of $8.3 \%$ in Besdolus bicolor (Navás) and 7.7\% in Perlodes microcephalus (Pictet). For chloroperlids, Weiss et al. (2012) found maximum divergences of $6.2 \%$ in Siphonoperla torrentium (Pictet) and $5.1 \%$ in S. hajastanica (Zhiltzova). For gripopterygids, Mynott et al. (2011) reported an intraspecific divergence of 5.8\% in Riekoperla alpina McLellan and $4.2 \%$ in $R$. karki McLellan. Mynott et al. (2011) pointed out that these high values could be related to geographic isolation among populations at high altitudes and might indicate the presence of cryptic species. Most species of Kempnyia in our study, e.g., K. colossica, K. gracilenta, and $K$. obtusa, show high intraspecific divergences, and these species have been collected in isolated mountain ranges in southeastern Brazil. High genetic divergences found in Kempnyia may be the result of the generally low vagility (Boumans and Baumann 2012) and conservative morphology of stoneflies, which makes it difficult to find reliable diagnostic characteristics for differentiating isolated populations or cryptic species.

In contrast, the populations of $K$. petersorum we studied were relatively homogeneous. Five individuals from Macaé River Basin shared the same haplotype, even though some were collected in localities separated by $\sim 35 \mathrm{~km}$ and $800 \mathrm{~m}$ in altitude. The highest divergences among $K$. petersorum individuals were found between a specimen from Paraná State (Morretes) and all other specimens from Rio de Janeiro State (Petrópolis and Macaé) (2.6-4.6\%; ENT418 vs ENT1184 and ENT243 vs ENT246). These localities were separated by $\sim 700 \mathrm{~km}$. Nevertheless, $K$. petersorum shares a pair of lateral spinose patches on the membranous penial tube (Froehlich 2011b) 
with $K$. neotropica and a few other Kempnyia species, including K. auberti Froehlich, K. ocellata Froehlich, K. sazimai Froehlich, K. tupinamba, K. umbrina Froehlich, and $K$. vanini. Some of these species are very similar in genital morphology, and are distinguished only by color pattern and size (Froehlich 1996). The distinction of these nominal species based on color pattern may be problematic because we found 2 color morphs of $K$. petersorum male and female adults in Macaé River Basin. The light color morph (Fig. 4I) matches Froehlich's (1996, 2011b) description based on specimens from São Paulo State, which have a distinctly stramineous head with a longitudinal brown band and uniformly brown pronotum, and is represented in our study by male specimens from Macaé River Basin [ENT83] and Paraná State [ENT246, 1183, and 1184]. Other $K$. petersorum males from Macaé River Basin in our study were dark brown (Fig. 4E), occurred in the same collecting sites, and shared the same size and penial armature with the light morph. This is the first reported case of color dimorphism in Kempnyia. Given the high morphological similarity, color plasticity, and the low interspecific divergences (relative to other divergences in our study) among members of this group of species (7.5-8.9\% interspecific divergences in Fig. 2; ENT242 vs ENT1183 and ENT242 vs ENT1184]), it is possible that $K$. petersorum, K. neotropica, and perhaps other related nominal species belong to the same species.

\section{Kempnyia from Macaé River Basin}

Knowledge of species-level identification and geographic range is essential for ecosystem conservation. This level of understanding is nascent for most Neotropical aquatic insects. Among the 15 Kempnyia species recorded from Rio de Janeiro State, only 4 had been described from Macaé River Basin based on material collected by E. Garbe in the early 1900s (Froehlich 1988, 2010, Nessimian et al. 2009). A new species was described recently based on material collected in 1996 and deposited in DZRJ (AvelinoCapistrano et al. 2013). Thus, our study increases these numbers to 11 species from Macaé River Basin and 17 from Rio de Janeiro State.

Currently, stonefly species from Rio de Janeiro State make up $24 \%$ of the total number of species recorded from Brazil, a percentage that is similar to the $27 \%$ in Trichoptera and 23\% in Ephemeroptera (Salles et al. 2013, Santos et al. 2013). The area of this state is $<1 \%$ of the area of Brazil, so the high proportion of recorded species in the state probably is a reflection of the early establishment of research centers in the region. However, historical inventories were done in only a few areas and little is known about the insect fauna in the rest of the state, especially in the northern region (Couri et al. 2009). The information on Plecoptera is very sparse because of a lack of specialists and focused diversity studies (Nessimian et al. 2009). Kempnyia taunayi and $K$. serrana were recorded in early collections (Froehlich 2010), but they did not occur in our samples.

Kempnyia taunayi was described by Navás (1936) based on 1 adult female, previously synonymized by Jewett (1960) with K. klugii (Pictet). Froehlich (2010) did not treat this species as a synonym, but as a species inquirenda, probably because Plecoptera females have a few diagnostic characters, and species diagnoses are based mostly on male genitalia. On the other hand, $K$. serrana has been recorded from Rio de Janeiro, Espírito Santo, and São Paulo states (Froehlich 2011b). We might have failed to collect it because it might not be attracted to light traps, as is the case for $K$. tenebrosa (Froehlich 2011b). Use of additional traps, like Malaise taps, might increase the efficiency of collecting events.

Our work contributes significantly to nymphal taxonomy and increases the number of Kempnyia nymphs described to species level from 5 to 9 . Descriptions of nymphs are common from the Nearctic and Palearctic regions (Claassen 1931, Hynes 1940, Zhiltzova et al. 2012) and are becoming more common from the Neotropics (Dorvillé and Froehlich 2001, Bispo and Froehlich 2008, Avelino et al. 2011, Bispo et al. 2013). In general, reliable diagnostic characters for separating nymphs to species level are few, and authors do not agree on which characters to use. Many authors have used coloration and external morphology to describe nymphs (Claassen 1931, Dorvillé and Froehlich 2001, Bispo and Froehlich 2008, Avelino-Capistrano et al. 2011, Bispo et al. 2013). We attempted to find new diagnostic characters by using SEMs, but we found none other than those that can be observed with light microscopy. However, we did find 1 important character, the absence of anal gills for 2 species of Kempnyia, K. obtusa, and $K$. petersorum, not previously observed in other described nymphs, and it seems to be of diagnostic relevance.

\section{Conclusions}

We are the first to use molecular tools to associate life stages of Neotropical stoneflies. Molecular associations to identified adult male Kempnyia, a southern South American genus from Macaé River Basin, resulted in identification of 6 nymphal morphotypes. Of the 6 Kempnyia species identified, 4 of those lacked formal morphological descriptions of their immature stages. These descriptions will enable morphological identification of immatures occurring in this basin at the species level, which will help refine biotic indices for freshwater monitoring. During our 3-y inventory, adult males of 2 of these species were not collected. Had these nymphs not been associated using DNA barcodes to identified males from other regions in Brazil, these species would have been neglected as oc- 
curring in this basin. Our study is far from being a comprehensive study that resolves species limits in Kempnyia, but it contributes to our knowledge of haplotype diversity in stonefly populations, which may be useful to future barcode identifications of Kempnyia individuals in southeastern Brazil for a wide variety of ecological and monitoring studies. Our study also revealed interesting aspects of stonefly morphological taxonomy (e.g., color polymorphism) that should be better addressed. In our opinion DNA barcode associations provided an easy and effective means to identify immature stages of Neotropical stoneflies and should be a standard method for associating stages when rearing of immatures is not possible.

\section{ACKNOWLEDGEMENTS}

We are grateful to Conselho Nacional de Desenvolvimento Científico e Tecnológico (CNPq, procs. 470.316/2009 and 481.554/2012) and Fundação Carlos Chagas Filho de Amparo à Pesquisa do Estado do Rio de Janeiro (FAPERJ, procs. E-26/ $171.281 / 2006$ and E26/111.389/2010) for partially funding this study. Fellowships from Coordenação de Aperfeiçoamento de Pessoal de Nível Superior (CAPES) and CNPq to FACS and JLN, respectively, are also appreciated. This manuscript highly benefited from comments and suggestions made by editors P. Silver and B. Sweeney and 2 anonymous referees on a previous version. We thank L. S. Barbosa for the suggestions on photographs. For sharing important literature, we thank L. Lecci, R. Fochetti, W. Graf, and C. Froehlich, who also shared his own illustrations of the genitalia of the type of $K$. varipes, so that a correct identification of our material could be made. S. Freitas helped with some SEMs at Rudolf Barth Electron Microscopy Platform of Instituto Oswaldo Cruz. Last, we thank all colleagues who helped with field work: A. L. Henriques-Oliveira, A. P. M. Santos, B. Clarkson, B. H. L. Sampaio, G. A. Jardim, I. C. Gonçalves, L. L. Dumas, L. F. L. Silveira, M. R. Souza, N. Ferreira Jr., R. A. Carvalho, and V. P. Alecrim.

\section{LITERATURE CITED}

Altschul, S. F., T. L. Madden, A. A. Schaffer, J. Zhang, Z. Zhang, W. Miller, and D. J. Lipman. 1997. Gapped BLAST and PSIBLAST: a new generation of protein search programs. Nucleic Acids Research 25:3389-3402.

Avelino-Capistrano, F. 2010. Plecoptera (Insecta) da Estação Biológica de Santa Lúcia, Espírito Santo, Brasil: distribuição espacial, sazonal e preferência por substratos. MS Thesis, Universidade Federal Rural do Rio de Janeiro, Rio de Janeiro, Brazil.

Avelino-Capistrano, F. S., L. S. Barbosa, and G. L. Almeida. 2011. Complementary descriptions of Kempnyia gracilenta (Enderlein 1909) and Kempnyia reticulata (Klapálek 1916) (Plecoptera: Perlidae). Illiesia 7:142-147.

Avelino-Capistrano, F. S., M. R. Souza, and J. L. Nessimian. 2013. Kempnyia puri, a new species of Plecoptera (Perlidae) from Rio de Janeiro, Brasil. Zootaxa 3619:554-556.

Bae, B. Y. J., H. K. Kil, and K. S. Bae. 2005. Benthic macroinvertebrates for uses in stream biomonitoring and restoration. Journal of Civil Engineering 9:55-63.
Baldin, C., P. C. Bispo, and M. C. Novaes. 2013. New species and records of Anacroneuria (Plecoptera: Perlidae) from Rio de Janeiro State, Brazil. Zootaxa 3694:391-397.

Baptista, D. F., L. F. M. Dorvillé, D. F. Buss, J. L. Nessimian, and L. H. J. Soares. 1998. Distribuição de comunidades de insetos aquáticos no gradiente longitudinal de uma bacia fluvial do Sudeste brasileiro. Pages 209-222 in J. L. Nessimian and A. L. Carvalho (editors). Ecologia de Insetos Aquáticos, Series Oecologia Brasiliensis, Volume V. Universidade Federal do Rio de Janeiro, Rio de Janeiro, Brazil.

Bergsten, J., D. T. Bilton, T. Fujisawa, M. Elliott, M. T. Monaghan, M. Balke, L. Hendrich, J. Geijer, J. Herrmann, G. N. Foster, I. Ribera, A. N. Nilsson, T. G. Barraclough, and A. P. Vogler. 2012. The effect of geographical scale of sampling on DNA barcoding. Systematic Biology 61:851-869.

Bispo, P. C., and C. G. Froehlich. 2008. Description of the larvae and redescription of the adult of Kempnyia neotropica Jacobsen \& Bianchi (Plecoptera: Perlidae) with biological notes. Aquatic Insects 30:61-67.

Bispo, P. C., R. Leite, and L. S. Lecci. 2013. Description of the larva of Kempnyia colossica (Navás) (Plecoptera: Perlidae) with biological notes. Aquatic Insects 35:1-5.

Boumans, L., and R. W. Baumann. 2012. Amphinemura palmeni is a valid Holarctic stonefly species (Plecoptera: Nemouridae). Zootaxa 3537:59-75.

Buss, D. F., D. F. Baptista, M. P. Silveira, J. L. Nessimian, and L. F. M. Dorvillé. 2002. Influence of water chemistry and environmental degradation on macroinvertebrate assemblages in a river basin in south-east Brazil. Hydrobiologia 481:125-136.

Callisto, M., M. Moretti, and M. Goulart. 2001. Macroinvertebrados bentônicos como ferramenta para avaliar a saúde de riachos. Revista Brasileira de Recursos Hídricos 6:71-82.

Caterino, M. S., and A. K. Tishechkin. 2006. DNA identification and morphological description of the first confirmed larvae of Hetaeriinae (Coleoptera: Histeridae). Systematic Entomology 31:405-418.

Claassen, P. W. 1931. Plecoptera nymphs of America (North Mexico). Memoirs of the Cornell University Agricultural Experiment Station 232. Thomas Say Foundation, Volumes III, VI.

Couri, M. S., J. L. Nessimian, G. Mejdalani, M. L. Monné, S. M. Lopes, M. C. Mendonça, R. Monteiro, S. Buys, and R. A. Carvalho. 2009. Levantamento dos insetos da Mata Atlântica do Estado do Rio de Janeiro. Arquivos do Museu Nacional 67:151-154.

Derka, T., J. M. Tierno de Figueroa, and M. Gamboa. 2009. First records of Plecoptera from Pantepui biogeographical province, with the first record of genus Kempnyia Klapálek, 1914 for Venezuela (Insecta: Plecoptera). Boletín de la Asociación Española de Entomología 33:493-502.

Dorvillé, L. F. M., and C. G. Froehlich. 2001. Description of the nymph of Kempnyia tijucana Dorvillé and Froehlich (Plecoptera, Perlidae), with notes on its development and biology. Trends in Research in Ephemeroptera and Plecoptera 13: 385-392.

Enderlein, G. 1909. Klassifikation der Plecopteropteren, sowie Diagnosen neuer Gattungen und Arten. Zoologischer Anzeiger 34:385-419. 
Fochetti, R., B. Gaetani, S. Fenoglio, T. Bo, M. J. LópezRodríguez, and J. M. Tierno-de-Figueroa. 2011. Systematics and biogeography of the genus Besdolus Ricker, 1952 (Plecoptera, Perlodidae): molecules do not match morphology. Zootaxa 3067:49-58.

Fochetti, R., E. Sezzi, J. M. Tierno-de-Figueroa, M. V. Modica, and M. Oliveiro. 2009. Molecular systematics and biogeography of the western Mediterranean stonefly genus Tyrrhenoleuctra (Insecta, Plecoptera). Journal of Zoological Systematics and Evolutionary Research 47:328-336.

Folmer, O., M. Black, W. Hoeh, R. Lutz, and R. Vrijenhoek. 1994. DNA primers for application of mitochondrial cytochrome $c$ oxidase subunit I from diverse metazoan invertebrates. Molecular Marine Biology and Biotechnology 3: 294-299.

Froehlich. C. G. 1984. Brazilian Plecoptera 2. Species of the serrana-group of Kempnyia (Plecoptera). Aquatic Insects 6: 137-147.

Froehlich, C. G. 1988. Brazilian Plecoptera 5. Old and new species of "Kempnyia" (Perlidae). Aquatic Insects 10:153-170.

Froehlich, C.G. 1996. Two new species of Kempnyia from southern Brazil (Plecoptera: Perlidae). Bulletin de la Société Entomologique Suisse 69:117-120.

Froehlich, C. G. 2010. Catalogue of Neotropical Plecoptera. Illiesia 6:118-205.

Froehlich, C. G. 2011a. Kempnyia (Plecoptera) from the Mantiqueira Mountains of Brazil. Zootaxa 2999:20-32.

Froehlich, C. G. 2011b. Notes on Kempnyia, with description of three new species (Plecoptera: Perlidae). Illiesia 7:133-141.

Galdean, N., M. Callisto, and F. A. R. Barbosa. 2000. Lotic ecosystems of Serra do Cipó, southeast Brazil: water quality and a tentative classification based on the benthic macroinvertebrate community. Aquatic Ecosystem Health and Management 3:545-552.

Galtier, N., B. Nabholz, S. Glémin, and D. D. Hurst. 2009. Mitochondrial DNA as marker of molecular diversity: a reappraisal. Molecular Ecology 18:4541-4550.

Gray, D. P. 2009. A new species of Zelandobius (Plecoptera: Gripopterygidae: Antarctoperlinae) from upper Rangitata River, Canterbury, New Zealand. New Zealand Journal of Marine and Freshwater Research 43:605-611.

Hajibabaei, M., S. Shokralla, X. Zhou, G. A. Singer, and D. J. Baird. 2011. Environmental barcoding: a next-generation sequencing approach for biomonitoring applications using river benthos. PLoS ONE 6:e17497.

Hayashi, M., and T. Sota. 2010. Identification of elmid larvae (Coleoptera: Elmidae) from Sanin District of Honshu, Japan, based on mitochondrial DNA sequences. Entomological Science 13:417-424.

Hebert, P. D. N., A. Cywinska, S. L. Ball, and J. R. deWaard. 2003a. Biological identifications through DNA barcodes. Proceedings of the Royal Society of London Series B: Biological Sciences 270:313-321.

Hebert, P. D. N., S. Ratnasingham, and J. R. deWaard. 2003b. Barcoding animal life: cytochrome $c$ oxidase subunit I divergences among closely related species. Proceedings of the Royal Society of London Series B: Biological Sciences 270:96-99.

Henriques-Oliveira, A. L., and J. L. Nessimian. 2010. Aquatic macroinvertebrate diversity and composition in streams along an altitudinal gradient in Southeastern Brazil. Biota Neotropica 10:115-128.

Hynes, H. B. N. 1940. A key to British species of Plecoptera (Stoneflies), with notes on their ecology. Freshwater Biological Association of the British Empire: Scientific Publications 2:1-39.

Jewett, S. G. J. 1960. Notes and descriptions concerning Brazilian stoneflies. Arquivos do Museu Nacional 1:167-183.

Jones, F. C. 2008. Taxonomic sufficiency: the influence of taxonomic resolution on freshwater bioassessments using benthic macroinvertebrates. Environmental Reviews 16:45-69.

Junqueira, V. M., and S. C. M. Campos. 1998. Adaptation of the "BMWP" method for water quality evaluation to Rio das Velhas watershed (Minas Gerais, Brazil). Acta Limnologica Brasiliensia 10:125-135.

Klapálek, F. 1916. Subfamilia Acroneuriinae Klp. Časopis České Společnosti Entomologické 13:45-84.

Miller, K. B., Y. Alarie, G. W. Wolfe, and M. F. Whiting. 2005. Association of insect life stages using DNA sequences: the larvae of Philodytes umbrinus (Motschulsky) (Coleoptera: Dytiscidae). Systematic Entomology 30:499-509.

Miserendino, M. L., and L. A. Pizzolón. 1999. Rapid assessment of river water quality using macroinvertebrates: a family level biotic index for the Patagonic Andean Zone. Acta Limnologica Brasiliensia 11:137-148.

Mugnai, R., R. B. Oliveira, A. L. Carvalho, and D. F. Baptista. 2008. Adaptation of the Indice Biotico Esteso (IBE) for water quality assessment in rivers of Serra do Mar, Rio de Janeiro State, Brazil. Tropical Zoology 21:57-74.

Müller, K. 1954. Investigations on the organic drift in North Swedish streams. Report of the Institute of Freshwater Research of Drottningholm 35:133-148.

Mynott, J. H., J. M. Webb, and P. J. Suter. 2011. Adult and larval associations of the alpine stonefly genus Riekoperla McLellan (Plecoptera: Gripopterygidae) using mitochondrial DNA. Invertebrate Systematics 25:11-21.

Navás, L. 1934. Família Pérlidos. Insectos suramericanos. Revista de la Real Academia de Ciencias de Madrid 31:22-23, 160-163.

Navás, L. 1936. Plecópteros. Pages 726-732 in Insectos del Brasil. 5a. Serie. Revista do Museu Paulista 20:721-734.

Nessimian, J. L., F. S. Avelino-Capistrano, B. L. Correia, and J. M. Costa. 2009. Espécies de Plecoptera (Insecta) registradas no Estado do Rio de Janeiro, Brasil. Arquivos do Museu Nacional 67:313-319.

Novaes, M. C., P. C. Bispo, and J. Higuti. 2012. A description of the nymph of Anacroneuria ofaye Froehlich (Plecoptera: Perlidae) and an apparatus for rearing Neotropical stonefly species. Zootaxa 3547:71-77.

Park, D., R. Foottit, E. Maw, and P. D. N. Hebert. 2011. Barcoding bugs: DNA-based identification of the true bugs (Insecta: Hemiptera: Heteroptera). PLoS ONE 6:e18749.

Posada, D. 2008. jModelTest: phylogenetic model averaging. Molecular Biology and Evolution 25:1253-1256.

Renaud, A. K., J. Savage, and S. J. Adamowicz. 2012. DNA barcoding of northern Nearctic Muscidae (Diptera) reveals high correspondence between morphological and molecular species limits. BMC Ecology 12:1-15.

Ronquist, F., M. Teslenko, P. van der Mark, D. L. Ayres, A. Darling, S. Höhna, B. Larget, L. Liu, M. A. Suchard, and J. P. Huelsenbeck. 2013. MrBayes 3.2: efficient Bayesian phyloge- 
netic inference and model choice across a large model space. Systematic Biology 61:539-542.

Rosenberg, D. M., and V. H. Resh. 1993. Introduction to freshwater biomonitoring and benthic macroinvertebrates. Pages 1-9 in D. M. Rosenberg and V. H. Resh (editors). Freshwater biomonitoring and benthic macroinvertebrates. Chapman and Hall, London, UK.

Salles, F. F., R. Boldrini, J. C. M. Nascimento, E. A. Raimundi, and Y. F. Shimano. 2013. Ephemeroptera do Brasil. Universidade Federal do Rio de Janeiro, Rio de Janeiro, Brazil. (Available from: https://sites.google.com/site/ephemeropterabr/)

Santos, A. P. M., L. L. Dumas, G. A. Jardim, A. L. R. Silva, and J. L. Nessimian. 2013. Brazilian caddisflies: checklists and bibliography. Universidade Federal do Rio de Janeiro, Rio de Janeiro, Brazil. (Available from: https://sites.google.com/site /braziliancaddisflies)

SEMADS (Secretaria de Estado de Meio-Ambiente e Desenvolvimento). 2001. Bacias Hidrográficas e Rios Fluminenses Síntese Informativa por Macrorregião Ambiental. Secretaria de Estado de Meio Ambiente e Desenvolvimento, Rio de Janeiro, Brasil. (Available from: http://www.ciflorestas.com.br /arquivos/doc_bacias_ambiental_18875.pdf)

Simon, C., F. Frati, A. Beckenbach, B. Crespi, H. Liu, and P. Flook. 1994. Evolution, weighting and phylogenetic utility of mitochondrial gene sequences and compilation of conserved polymerase chain reaction primers. Annals of the Entomological Society of America 87:651-701.

Stark, B. P., C. G. Froehlich, and M. C. Zúñiga. 2009. South American stoneflies (Plecoptera). Volume 5. Aquatic biodiversity in Latin America. Pensoft, Sofia-Moscow, Russia.

Sweeney, B. W., J. M. Battle, and J. K. Jackson. 2011. Can DNA barcodes of stream macroinvertebrates improve descriptions of community structure and water quality? Journal of the North American Benthological Society 30:195-216.

Tamura, K., D. Peterson, N. Peterson, G. Stecher, M. Nei, and S. Kumar. 2011. MEGA5: molecular evolutionary genetics analysis using maximum likelihood, evolutionary distance, and maximum parsimony methods. Molecular Biology and Evolution 28:2731-2739.

Tierno-de-Figueroa, J. M., B. Gaetani, J. M. Luzón-Ortega, M. J. López-Rodrigues, and R. Fochetti. 2011. On the identity of Isoperla curtata (Plecoptera: Perlodidae): behavioural and molecular approaches show the existence of two separate species. Zootaxa 3000:49-58.

Thompson, J. D., D. G. Higgins, and T. J. Gibson. 1994. Clustal W: improving the sensitivity of progressive multiple sequence alignment through sequence weighting, position-specific gap penalties and weight matrix choice. Nucleic Acids Research 22:4673-4680.

Trivinho-Strixino, S., M. Pepinelli, T. Siqueira, and F. O. Roque. 2012. DNA barcoding of Podonomus (Chironomidae, Podonominae) enables stage association of a named species and reveals hidden diversity in Brazilian inselbergs. Annales de Limnologie 48:411-423.

Weiss, S., D. Stradner, and W. Graf. 2012. Molecular systematics, evolution and zoogeography of the stonefly genus Siphonoperla (Insecta: Plecoptera, Chloroperlidae). Journal of Zoological Systematics and Evolutionary Research 50: 19-29.

Zhiltzova, L. A., S. K. Cherchesova, and I. E. Dzhioeva. 2012. Description of the larva of the Caucasian species Protonemura microstyla Martynov (Plecoptera, Nemouridae). Illiesia 8:158-161.

Zhou, X., S. J. Adamowicz, L. M. Jacobus, R. E. DeWalt, and P. D. N. Hebert. 2009. Toward a comprehensive barcode library for Arctic life-Ephemeroptera, Plecoptera, and Trichoptera of Churchill, Manitoba, Canada. Frontiers in Zoology 6:1-30.

Zhou, X., K. M. Kjer, and J. C. Morse. 2007. Associating larvae and adults of Chinese Hydropsychidae caddisflies (Insecta: Trichoptera) using DNA sequences. Journal of the North American Benthological Society 26:719-742. 